\title{
LONGITUDINAL AND RADIAL VARIATION OF EXTRACTIVES AND TOTAL LIGNIN CONTENTS IN A CLONE OF Eucalyptus grandis W.Hill ex Maiden x Eucalyptus urophylla S. T. Blake
}

\author{
Marina Donária Chaves Arantes¹, Paulo Fernando Trugilho², José Tarcísio Lima³, \\ Angélica de Cássia Oliveira Carneiro ${ }^{4}$ Eduardo Alves ${ }^{5}$ Mário César Guerreiro ${ }^{6}$
}

(received: January 14, 2010; accepted: April 28, 2011)

\begin{abstract}
The objective of this work was to determine concentrations of extractives and total lignin along with their radial and longitudinal variations in wood from a clone of Eucalyptus grandis W.Hill ex Maiden x Eucalyptus urophylla S. T. Blake at age six years. Longitudinal samples were taken at $2 \%, 10 \%, 30 \%$ and $70 \%$ of the commercial height of trees, and radial samples were taken from each longitudinal position, the number of samples depending on the diameter of each disk. Results led to the conclusion that, overall, concentrations of extractives and total lignin in the wood tended to decrease with increasing distance from the pith and tended to increase in portions closer to the tree base.
\end{abstract}

Key words: Wood, Eucalyptus, chemical components.

\section{VARIAÇÃO LONGITUDINAL E RADIAL DOS TEORES DE EXTRATIVOS E LIGNINA TOTAL DO CLONE DE Eucalyptus grandis W.Hill ex Maiden x Eucalyptus urophylla S. T. Blake}

RESUMO: Objetivou-se, com este trabalho, determinar os teores de extrativos e lignina total e suas variações radiais e longitudinais na madeira do clone de Eucalyptus grandis W.Hill ex Maiden x Eucalyptus urophylla S. T. Blake, aos seis anos de idade. Foram retiradas amostras no sentido longitudinal a 2, 10, 30 e 70\% da altura comercial da árvore, e no sentido radial de cada posição longitudinal, sendo que o número de amostras dependeu do diâmetro do disco. Pelos resultados obtidos, concluiu-se que: os teores de extrativos e lignina total na madeira apresentaram, em geral, variação decrescente com a distância da medula e tenderam a uma maior concentração nas regiões mais próximas à base das árvores.

Palavras-chave: Madeira, Eucalyptus, componentes químicos.

\section{INTRODUCTION}

When considering constituent elements of wood, a distinction should be made between the macromolecular components of the cell wall, namely cellulose, hemicelluloses and lignin.

Cellulose is the chief component of wood and accounts for half the material contained in both softwoods and hardwoods. It is characterized as a linear polymer of high molecular weight, composed exclusively of ß-Dglucose. Due to its chemical and physical properties as well as its supramolecular structure, it is the chief component of the cell wall of plants. Hemicelluloses, in turn, are in close relation with cellulose in the cell wall. Their molecular chains are much shorter than those in cellulose, there possibly being side groups and chain branching in some cases. Overall, hardwood has higher polyose contents than softwood, and its composition is differentiated (KLOCK et al., 2005).

Another constituent of the cell wall is lignin, an aromatic, three-dimensional, high molecular weight polymer, having hydroxylated and methoxylated phenylpropane as a structural base, depending on the type of wood. Lignin is closely associated with hemicelluloses, not only through physical interaction but also through chemical bonding (BARRICHELO; BRITO, 1985). Lignin is considered more hydrophobic than other wood components and thus acts as a cementing, adhesive material among fibers (PETTERSEN, 1984), besides imparting hardness and stiffness to the cell wall.

\footnotetext{
${ }^{1}$ Forest Engineer, Professor, Ph.D. in Wood Science and Technology - Centro de Ciências Agrárias/CCA - Universidade Federal do Espírito Santo/UFES 29.500-000 - Alegre, ES, Brasil - mdonariac@hotmail.com

${ }^{2}$ Forest Engineer, Professor, Ph.D. in Forest Science - Departamento de Ciências Florestais - Universidade Federal de Lavras - Cx. P. 3037 - 37200-000 Lavras, MG, Brasil - trugilho@dcf.ufla.br

${ }^{3}$ Forest Engineer, Professor, Ph.D. in Forest Sciences - Departamento de Ciências Florestais/DCF - Universidade Federal de Lavras/UFLA - Cx.P. 3037 37200-000 - Lavras, MG, Brasil - jtlima@dcf.ufla.br

${ }^{4}$ Forest Engineer, Professor, Ph.D. in Forest Science - Departamento de Engenharia Florestal - Universidade Federal de Viçosa/UFV - 36570-000 Viçosa, MG, Brasil - cassinhacarneiro@yahoo.com.br

${ }^{5}$ Agonomic Engineer, Professor Ph.D. in Agronomy - Departamento de Fitopatologia - Universidade Federal de Lavras/UFLA - 37200-000 - Lavras, MG, Brasil - ealves@dfp.ufla.br

${ }^{6}$ Chemist, Professor Ph.D. in Chemistry - Departamento de Química/DQI - Universidade Federal de Lavras/UFLA - 37200-000 - Lavras, MG, Brasil-guerrero@dqi.ufla.br
}

Cerne, Lavras, v. 17, n. 3, p. 283-291, jul./set. 2011 
Information about variations in lignin content is scarce in literature, both longitudinally and radially in relation to the log.

In a study about variation of physicochemical characteristics in Eucalyptus wood with age, Trugilho et al. (1996) found a negative correlation between basic density and lignin content, suggesting that high lignin content woods have lower basic density. These authors concluded that chemical characteristics are subject to considerable initial variations in juvenile wood but tend to become more stable in mature wood.

The remaining components of wood, present in smaller quantities, are low molecular weight compounds known as extractives, which are found particularly in the bark and include terpenes, oils, gums, tannins, coloring matter etc.

According to Pereira et al. (2000), extractives are accidental chemical compounds unessential for the structure of the cell wall and middle lamella, being soluble in water or other neutral organic solvents. Among extractives, they cite terpenes, resins, volatile oils, gums, waxes and tannins.

According to Lima et al. (2007), volatile extractives known as essential oils are responsible for the characteristic odor of plants, being present in significant quantities in gymnosperms but in smaller proportion in angiosperms. These compounds are constituted by terpenes, alcohols, esters, aldehydes, ketones, organic acids, aliphatic hydrocarbons and low molecular weight phenols.

Silvério et al. (2006) studied a methodology for extraction and determination of extractives content in eucalyptus woods and observed that, for E. urophylla $\mathrm{x}$ E. grandis, the (2:1) toluene:ethanol mixture was more effective in removing total extractives, whose average content was $2.23 \%$.

The objective of this work was to determine concentrations of extractives and total lignin, along with their radial and longitudinal variations, in wood from a clone of Eucalyptus grandis W.Hill ex Maiden x Eucalyptus urophylla S. T. Blake at age six years.

\section{MATERIAL AND METHODS}

Fifty trees were sampled from a clonal stand of Eucalyptus urophylla x Eucalyptus grandis at age 6 years, planted with $3 \times 2 \mathrm{~m}$ spacing and provided by ArcelorMittal Florestas. The clonal stand was located in Martinho Campos, Minas Gerais State. In the sampling site, a plot consisting of 10 rows x 10 plants was launched and the diameter of all trees was measured for classification by diameter.
Three diameter classes were established and the number of sampled trees per class was defined by their participative percentage in relation to the population, as can be seen in Table 1. Once the number of individuals per diameter class was defined, trees within these intervals were selected.

Table 1 - Tree distribution in a clonal stand of Eucalyptus grandis W.Hill ex Maiden x Eucalyptus urophylla S. T. Blake according to diameter class.

Tabela 1 - Distribuição das árvores do clone de Eucalyptus grandis W.Hill ex Maiden x Eucalyptus urophylla S. T. Blake nas classes diamétricas

\begin{tabular}{lccc}
\hline Class (cm) & $\begin{array}{c}\text { Class midpoint } \\
(\mathrm{cm})\end{array}$ & Frequency & $\begin{array}{c}\text { Participation in } \\
\text { the population (\%) }\end{array}$ \\
\hline 12.8 to 17.0 & 14.2 & 23 & 47 \\
9.7 to 12.7 & 11.4 & 19 & 38 \\
3.1 to 9.5 & 8.1 & 8 & 15 \\
\hline Total & & 50 & 100 \\
\hline
\end{tabular}

For determination of the extractives and total lignin contents, longitudinal samples were taken from the $2 \%$, $10 \%, 30 \%$ and $70 \%$ log portions along the commercial height. As regards radial samples from each longitudinal position, the number of samples was conditional on the diameter of the disk (side $\mathrm{A}$ and side $\mathrm{B}$, considering the pith as midpoint). The reason for this alternative sampling being at the $2 \%, 10 \%, 30 \%$ and $70 \%$ portions of the commercial height was that these sections provided the best results in a study conducted by Pádua (2009) using the same clone of Eucalyptus grandis W.Hill ex Maiden $\mathrm{x}$ Eucalyptus urophylla S. T. Blake.

Extractives were measured according to standard $\mathrm{M}$ 3/69 of the Brazilian pulp and paper technical association, Associação Brasileira Técnica de Celulose e Papel - ABCP (1974). Insoluble lignin (Klason lignin) was measured according to descriptions by Gomide and Demuner (1986). The soluble lignin content in sulfuric acid was determined by spectrophotometry, using the equation described by Goldschimid (1971). The total lignin content resulted from the aggregate of soluble and insoluble lignin contents.

\section{RESULTS AND DISCUSSION}

Table 2 provides average values of total extractives according to radial and longitudinal position, for different diameter classes. A variation was found in the concentration of total extractives both in the radial and longitudinal sampling positions.

Cerne, Lavras, v. 17, n. 3, p. 283-291, jul./set. 2011 
Table 2 - Average values of total extractives according to radial and longitudinal positions, in wood from a clone of Eucalyptus grandis W.Hill ex Maiden x Eucalyptus urophylla S. T. Blake.

Tabela 2 - Valores médios dos teores de extrativos totais por posição radial e longitudinal da madeira do clone de Eucalyptus grandis W.Hill ex Maiden x Eucalyptus urophylla S. T. Blake.

\begin{tabular}{|c|c|c|c|c|c|c|c|c|c|c|c|c|}
\hline \multirow{3}{*}{$\begin{array}{l}\text { Height (\%) } \\
2\end{array}$} & \multirow{3}{*}{$\begin{array}{c}\text { Average } \\
3.8\end{array}$} & \multicolumn{10}{|c|}{$14.2 \mathrm{~cm}$ class } & \multirow{3}{*}{$\begin{array}{c}\text { Average } \\
3.99\end{array}$} \\
\hline & & \multicolumn{5}{|c|}{ Side A } & \multicolumn{5}{|c|}{ Side B } & \\
\hline & & 3.27 & 2.41 & 4.37 & 4.26 & 4.7 & 5.01 & 4.65 & 4.39 & 2.97 & 2.94 & \\
\hline 10 & 2.93 & 1.85 & 2.18 & 3.92 & 2.58 & 4.12 & 4.01 & 2.67 & 3.9 & 1.82 & 2.72 & 3.02 \\
\hline 30 & 2.66 & & 2.32 & 1.83 & 2.91 & 3.59 & 2.82 & 2.68 & 1.45 & 2.27 & & 2.31 \\
\hline 70 & 2.88 & & & & 3.32 & 2.44 & 3.3 & 1.99 & & & & 2.65 \\
\hline Average & & 2.56 & 2.3 & 3.37 & 3.27 & 3.71 & 3.79 & 3.33 & 3.25 & 2.4 & 2.83 & \\
\hline \multirow{2}{*}{ Height (\%) } & \multirow{2}{*}{ Average } & \multicolumn{10}{|c|}{$11.4 \mathrm{~cm}$ class } & \multirow{2}{*}{ Average } \\
\hline & & \multicolumn{5}{|c|}{ Side A } & \multicolumn{5}{|c|}{ Side B } & \\
\hline 2 & 3.96 & & 2.9 & 3.88 & 4.63 & 4.41 & 5.14 & 4.95 & 1.84 & 1.69 & & 3.41 \\
\hline 10 & 3.04 & & 2.44 & 2.66 & 3.16 & 3.92 & 3.27 & 3.13 & 1.86 & 4.14 & & 3.1 \\
\hline 30 & 2.61 & & & 2.82 & 2.61 & 2.41 & 2.75 & 2.3 & 2.43 & & & 2.49 \\
\hline 70 & 2.15 & & & & 2.33 & 1.97 & 3.27 & 2.52 & & & & 2.89 \\
\hline Average & & & 2.67 & 3.12 & 3.18 & 3.18 & 3.61 & 3.22 & 2.04 & 2.91 & & \\
\hline \multirow{2}{*}{ Height (\%) } & \multirow{2}{*}{ Average } & \multicolumn{10}{|c|}{$8.1 \mathrm{~cm}$ class } & \multirow{2}{*}{ Average } \\
\hline & & \multicolumn{5}{|c|}{ Side A } & \multicolumn{5}{|c|}{ Side B } & \\
\hline 2 & 4.5 & & & 2.9 & 4.33 & 6.28 & 6.34 & 2.7 & 2.61 & & & 3.88 \\
\hline 10 & 2.96 & & & 2.91 & 2.78 & 3.19 & 3.15 & 3.19 & 2.75 & & & 3.03 \\
\hline 30 & 1.88 & & & 1.32 & 2.43 & 1.9 & 2.1 & 2.31 & 1.83 & & & 2.08 \\
\hline 70 & 1.63 & & & & 1.91 & 1.34 & 1.21 & 2.66 & & & & 1.94 \\
\hline Average & & & & 2.38 & 2.86 & 3.18 & 3.2 & 2.71 & 2.4 & & & \\
\hline
\end{tabular}

As was observed in the $14.2 \mathrm{~cm}$ class, overall, the concentrations of extractives tend to decrease in the pith to bark direction, and the same pattern is noted for the 11.4 $\mathrm{cm}$ and $8.1 \mathrm{~cm}$ classes.

For the $14.2 \mathrm{~cm}$ class, an initial reduction is followed by an increase in the values of total extractives from the base to the top of trees. The $11.4 \mathrm{~cm}$ class showed the same pattern.

The average extractives content, all three diameter classes being considered, was 2.91\%, differing from values in literature. Silvério et al. (2006), for instance, while studying a methodology to extract and determine extractives in wood from Eucalyptus urophylla, E. camaldulensis and E. urophylla x E. grandis, found an average value of $2.23 \%$.

It was noted, for the $14.2 \mathrm{~cm}$ class, that the total extractives content tends to decrease up to the $30 \%$ height portion and then increase at the $70 \%$ height portion of the trunk. This increase is likely related to higher sugar quantities in taller parts of the trunk, closer to the apical meristem. Silva et al. (2005) investigated the influence of age and position relative to the trunk on the chemical composition of wood from Eucalyptus grandis Hill ex. Maiden and found that older, lower log sections had higher extractives and lignin contents than remaining log sections, corresponding to maturer wood, and they also found that younger, higher log sections had higher holocellulose contents.

For the $11.4 \mathrm{~cm}$ class, it was noted that the total extractives content tends to decrease up to the $30 \%$ height portion and then increase at the $70 \%$ height portion of the trunk. This increase is likely related to the higher concentration of low molecular weight carbohydrates in taller parts of the trunk, closer to the apical meristem. This data agree with values found in literature, as for instance results described by Silva et al. (2005).

For the $8.1 \mathrm{~cm}$ class, longitudinal variation in total extractives content tends to decrease considerably with increasing relative height and then stabilize at the 70\% height portion of the trunk.

Cerne, Lavras, v. 17, n. 3, p. 283-291, jul./set. 2011 
Figure 1 illustrates radial variation in total extractives content within the $14.2 \mathrm{~cm}$ class, per relative height. A decreasing tendency was noted in the extractives content with increasing distance from the pith, in all heights being considered, except the $70 \%$ height portion (side A). In the position closer to the bark an increasing tendency was noted in extractives content, possibly related to higher sugar contents in such areas, close to the vascular cambium. In the part facing the pith, the higher amount of extractives is likely related to heartwood formation and, consequently, more polyphenols present.

Figure 2 illustrates radial variation of total extractives content for diameter class $11.4 \mathrm{~cm}$, per relative height. A decreasing tendency in extractives content is noted with increasing distance from the pith, for the $2 \%$ and $10 \%$ height portions of the commercial trunk. This tendency is more noticeable at $2 \%$. At $10 \%$ (side B), an abrupt increase occurred in the position closer to the bark, possibly caused by the presence of resin pockets (kino), a very common occurrence in Eucalyptus wood. In positions closer to the bark there is an increasing tendency in the extractives content, possibly related to high sugar contents in such areas, close to the vascular cambium. In the part facing the pith, the higher amount of extractives is likely
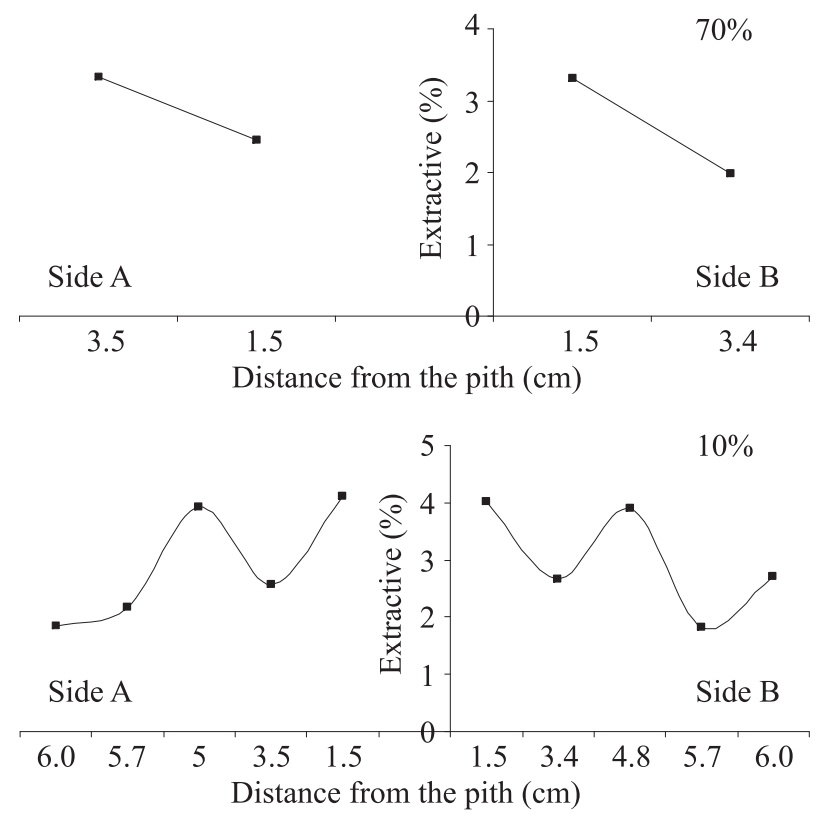

related to heartwood formation and, consequently, more polyphenols present. These results were similar to values found for the $14.2 \mathrm{~cm}$ class.

The radial variation of total extractives content for diameter class $8.1 \mathrm{~cm}$ per relative height is illustrated in Figure 3. The variation was found to be similar to that found in the other two diameter classes, as discussed earlier. In positions closer to the bark there is an increasing tendency in extractives content, possibly related to higher sugar contents in such areas, close to the vascular cambium. A higher content is observed at the $2 \%$ height portion, in comparison to classes $14.2 \mathrm{~cm}$ and $11.4 \mathrm{~cm}$. This reinforces the idea that these extractives are mainly composed of low molecular weight carbohydrates which are present in sapwood, and given that the diameter class $8.1 \mathrm{~cm}$ has low percentage of heartwood. Overall, results were similar to findings for diameter classes $11.4 \mathrm{~cm}$ and $14.2 \mathrm{~cm}$.

Average values of total lignin content, according to each relative height, radial position and diameter class, are illustrated in Table 3.

For longitudinal variation of lignin content in diameter class $14.2 \mathrm{~cm}$, overall, higher lignin contents were found in positions closer to the tree base.
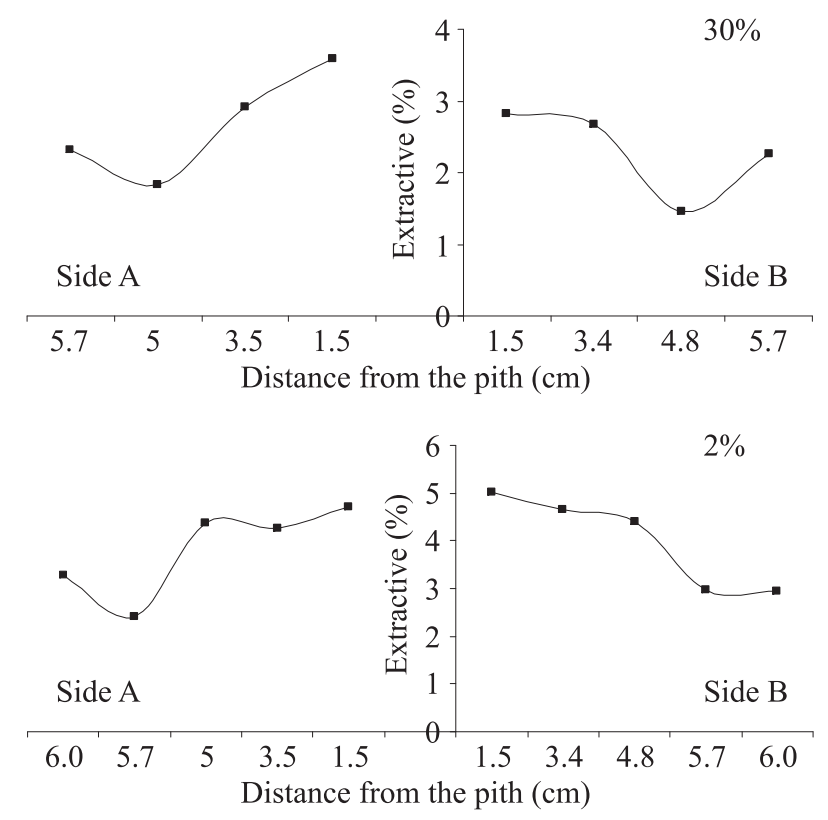

Figure 1 - Radial variation of total extractives content in wood from a clone of Eucalyptus grandis W.Hill ex Maiden x Eucalyptus urophylla S. T. Blake, for diameter class $14.2 \mathrm{~cm}$.

Figura 1 - Variação radial para o teor de extrativos totais da madeira do clone de Eucalyptus grandis W.Hill ex Maiden x Eucalyptus urophylla S. T. Blake para a classe diamétrica $14,2 \mathrm{~cm}$.

Cerne, Lavras, v. 17, n. 3, p. 283-291, jul./set. 2011 

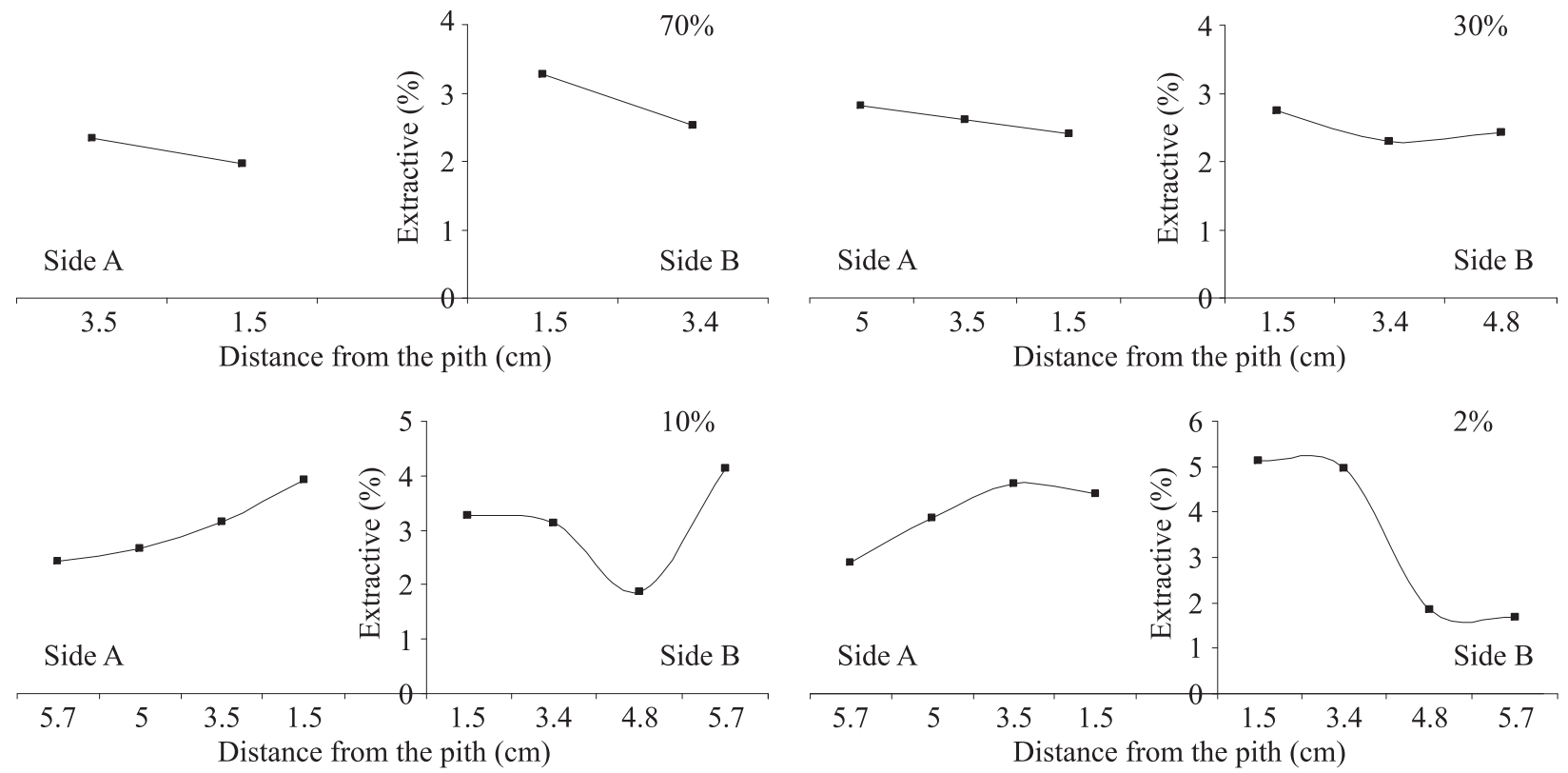

Figure 2 - Radial variation of total extractives content in wood from a clone of Eucalyptus grandis W.Hill ex Maiden x Eucalyptus urophylla S. T. Blake, for diameter class $11.4 \mathrm{~cm}$.

Figura 2 - Variação radial do teor de extrativos totais na madeira do clone de Eucalyptus grandis W.Hill ex Maiden x Eucalyptus urophylla S. T. Blake para a classe diamétrica $11,4 \mathrm{~cm}$.
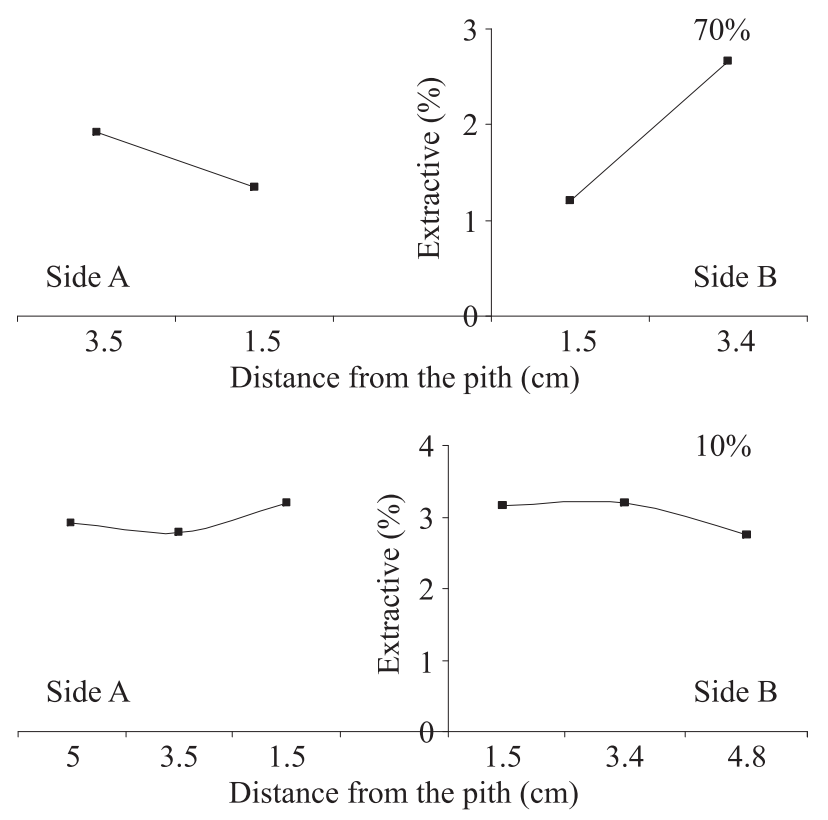
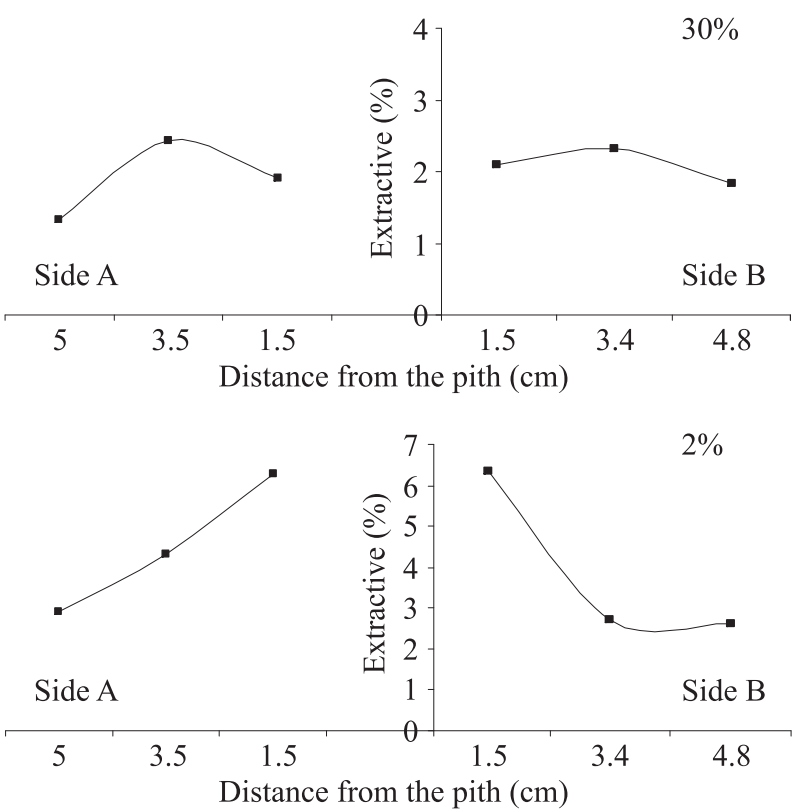

Figure 3 - Radial variation of total extractives content in wood from a clone of Eucalyptus grandis W.Hill ex Maiden x Eucalyptus urophylla S. T. Blake, for diameter class $8.1 \mathrm{~cm}$.

Figura 3 - Variação radial do teor de extrativos totais na madeira do clone de Eucalyptus grandis W.Hill ex Maiden x Eucalyptus urophylla S. T. Blake para a classe diamétrica $8,1 \mathrm{~cm}$.

Cerne, Lavras, v. 17, n. 3, p. 283-291, jul./set. 2011 
Table 3 - Average values of total lignin content (\%), according to each relative height, radial position and diameter class, in wood from a clone of Eucalyptus grandis W.Hill ex Maiden x Eucalyptus urophylla S. T. Blake.

Tabela 3 - Valores médios do teor de lignina total (\%) por altura relativa, posição radial de amostragem e classe diamétrica na madeira do clone de Eucalyptus grandis W.Hill ex Maiden x Eucalyptus urophylla S. T. Blake.

\begin{tabular}{|c|c|c|c|c|c|c|c|c|c|c|c|c|}
\hline \multirow{2}{*}{ Height (\%) } & \multirow{2}{*}{ Average } & \multicolumn{10}{|c|}{$14.2 \mathrm{~cm}$ class } & \multirow{2}{*}{ Average } \\
\hline & & \multicolumn{5}{|c|}{ Side A } & \multicolumn{5}{|c|}{ Side B } & \\
\hline 2 & 31.26 & 28.7 & 23.96 & 34.19 & 38.18 & 31.25 & 35.76 & 33.82 & 31.83 & 27.49 & 30.74 & 31.93 \\
\hline 10 & 32.12 & 37.22 & 27.67 & 30.6 & 29.7 & 30.97 & 30.92 & 31.5 & 36.35 & 27.82 & 35.69 & 32.46 \\
\hline 30 & 30.26 & & 32.43 & 28.99 & 28.06 & 31.56 & 31.85 & 28.84 & 30.65 & 28.03 & & 29.84 \\
\hline 70 & 30.45 & & & & 29.68 & 31.21 & 31.89 & 28.57 & & & & 30.23 \\
\hline Average & & 32.96 & 28.02 & 31.26 & 31.41 & 31.25 & 32.61 & 30.68 & 32.94 & 27.78 & 33.22 & \\
\hline \multirow{2}{*}{ Height (\%) } & \multirow{2}{*}{ Average } & \multicolumn{10}{|c|}{$11.4 \mathrm{~cm}$ class } & \multirow{2}{*}{ Average } \\
\hline & & & & Side A & & & & & Side B & & & \\
\hline 2 & 32.48 & & 31.92 & 33.81 & 32.09 & 32.11 & 30.29 & 25 & 31.36 & 27.46 & & 28.53 \\
\hline 10 & 30.15 & & 28.46 & 27.42 & 32.18 & 32.55 & 35.64 & 34.97 & 28.81 & 30.7 & & 32.53 \\
\hline 30 & 29.35 & & & 28.11 & 29.39 & 30.54 & 30.25 & 29.47 & 29.5 & & & 29.74 \\
\hline 70 & 29.59 & & & & 30.28 & 28.89 & 30.14 & 28.67 & & & & 29.41 \\
\hline Average & & & 30.19 & 29.78 & 30.98 & 31.02 & 31.58 & 29.53 & 29.89 & 29.08 & & \\
\hline \multirow{2}{*}{ Height (\%) } & \multirow{2}{*}{ Average } & \multicolumn{10}{|c|}{$8.1 \mathrm{~cm}$ class } & \multirow{2}{*}{ Average } \\
\hline & & \multicolumn{5}{|c|}{ Side A } & \multicolumn{5}{|c|}{ Side B } & \\
\hline 2 & 33.57 & & & 32.98 & 31.55 & 36.18 & 35.17 & 32.38 & 30.38 & & & 32.64 \\
\hline 10 & 29.39 & & & 25.87 & 29.75 & 32.54 & 31.82 & 29.93 & 27.9 & & & 29.89 \\
\hline 30 & 27.56 & & & 27.13 & 30.07 & 25.48 & 26.78 & 27.79 & 26.33 & & & 26.97 \\
\hline 70 & 27.82 & & & & 25.63 & 30.02 & 29.82 & 29.98 & & & & 29.9 \\
\hline Average & & & & 28.66 & 29.25 & 31.06 & 30.9 & 30.02 & 28.2 & & & \\
\hline
\end{tabular}

Similarly to diameter class $14.2 \mathrm{~cm}$, with diameter class $11.4 \mathrm{~cm}$ the highest lignin contents were overall found in positions close to the stem base. This could be related to greater proportion of heartwood in portions near the tree base. Haselein et al. (2004) observed a similar pattern, with heartwood percentage showing increasing average values from the base up to the $25 \%$ height portion and then decreasing until the $100 \%$ height portion, with a general average of $75.7 \%$. An increasing tendency exists in lignin content up to the $10 \%$ height portion, followed by a reduction and then stabilization at the $30 \%$ and $70 \%$ height portions of the commercial trunk.

For diameter class $8.1 \mathrm{~cm}$, higher lignin contents were found in base positions, particularly at the $2 \%$ height portion, similarly to diameter classes $14.2 \mathrm{~cm}$ and $11.4 \mathrm{~cm}$. This could be related to higher proportion of heartwood in portions close to the tree base, particularly in this small diameter class on account of the small percentage of heartwood present. A decrease was observed after the $2 \%$ height portion, and from the $10 \%$ height portion onward lignin contents remained more or less unchanged.
Figure 4 illustrates radial variation of total lignin content in wood from a clone of Eucalyptus grandis W.Hill ex Maiden x Eucalyptus urophylla S. T. Blake for diameter class $14.2 \mathrm{~cm}$ per relative height. The lignin content failed to show a well defined pattern of radial variation. Yet it was observed that, overall, higher lignin contents are found near the pith while lower lignin contents are found near the sapwood.

Lignin quantity is an important parameter for putting wood to different uses. As discussed by Andrade (1993), the chemical composition of wood exerts considerable influence over the physicochemical properties of charcoal inasmuch as when lignin rich wood is carbonized, a high gravimetric yield is obtained along with a high carbon content charcoal. This relates to greater resistance by lignin to thermal breakdown than by other structural components in wood.

Figure 5 provides radial variation of total lignin content in wood from a clone of Eucalyptus grandis W.Hill ex Maiden x Eucalyptus urophylla S. T. Blake for diameter class $11.4 \mathrm{~cm}$ per relative height. Here, the

Cerne, Lavras, v. 17, n. 3, p. 283-291, jul./set. 2011 

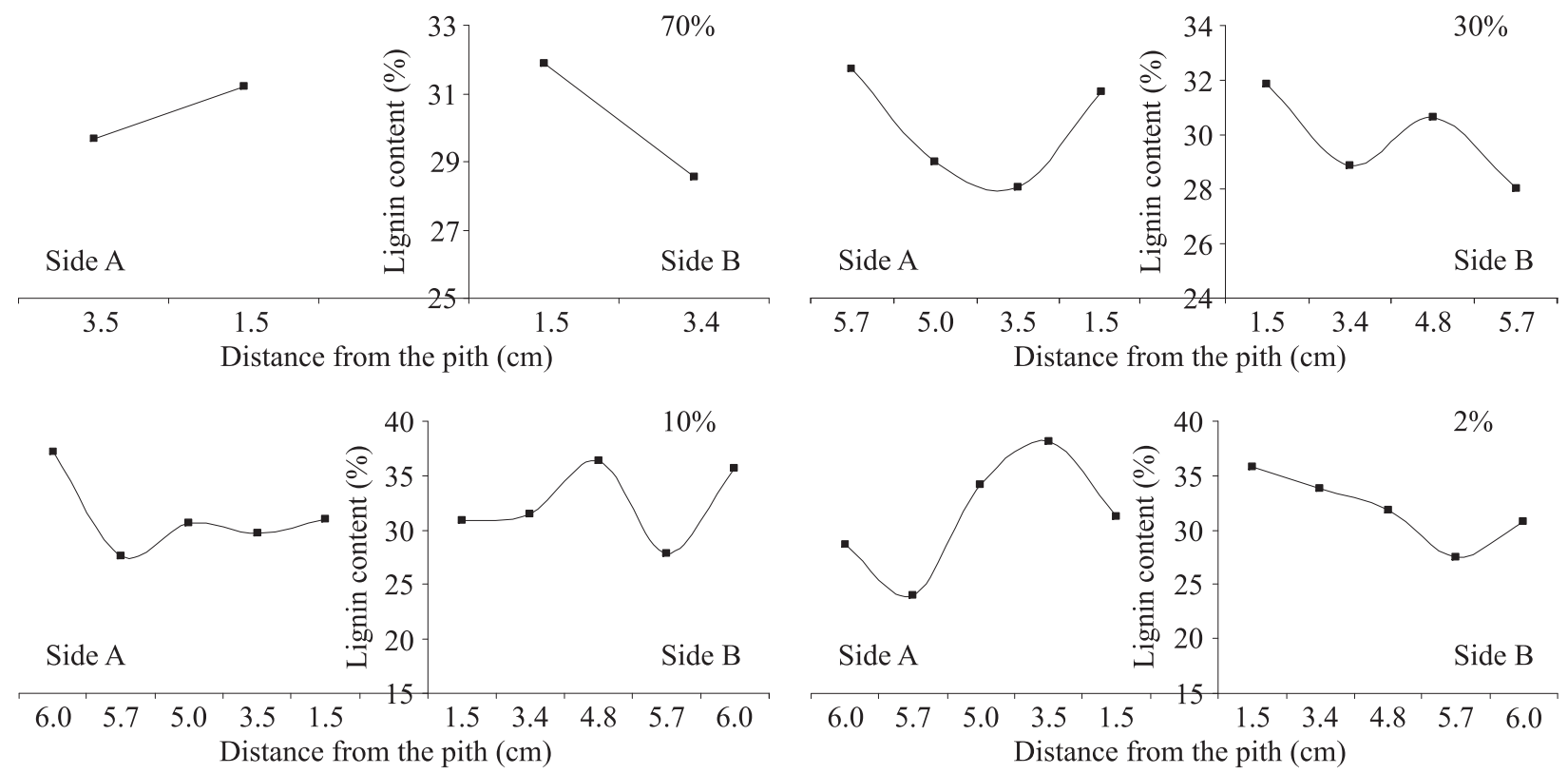

Figure 4 - Radial variation of total lignin content in wood from a clone of Eucalyptus grandis W.Hill ex Maiden x Eucalyptus urophylla S. T. Blake, for diameter class $14.2 \mathrm{~cm}$.

Figura 4 - Variação radial do teor de lignina total na madeira do clone de Eucalyptus grandis W.Hill ex Maiden x Eucalyptus urophylla S. T. Blake para a classe diamétrica $14,2 \mathrm{~cm}$.
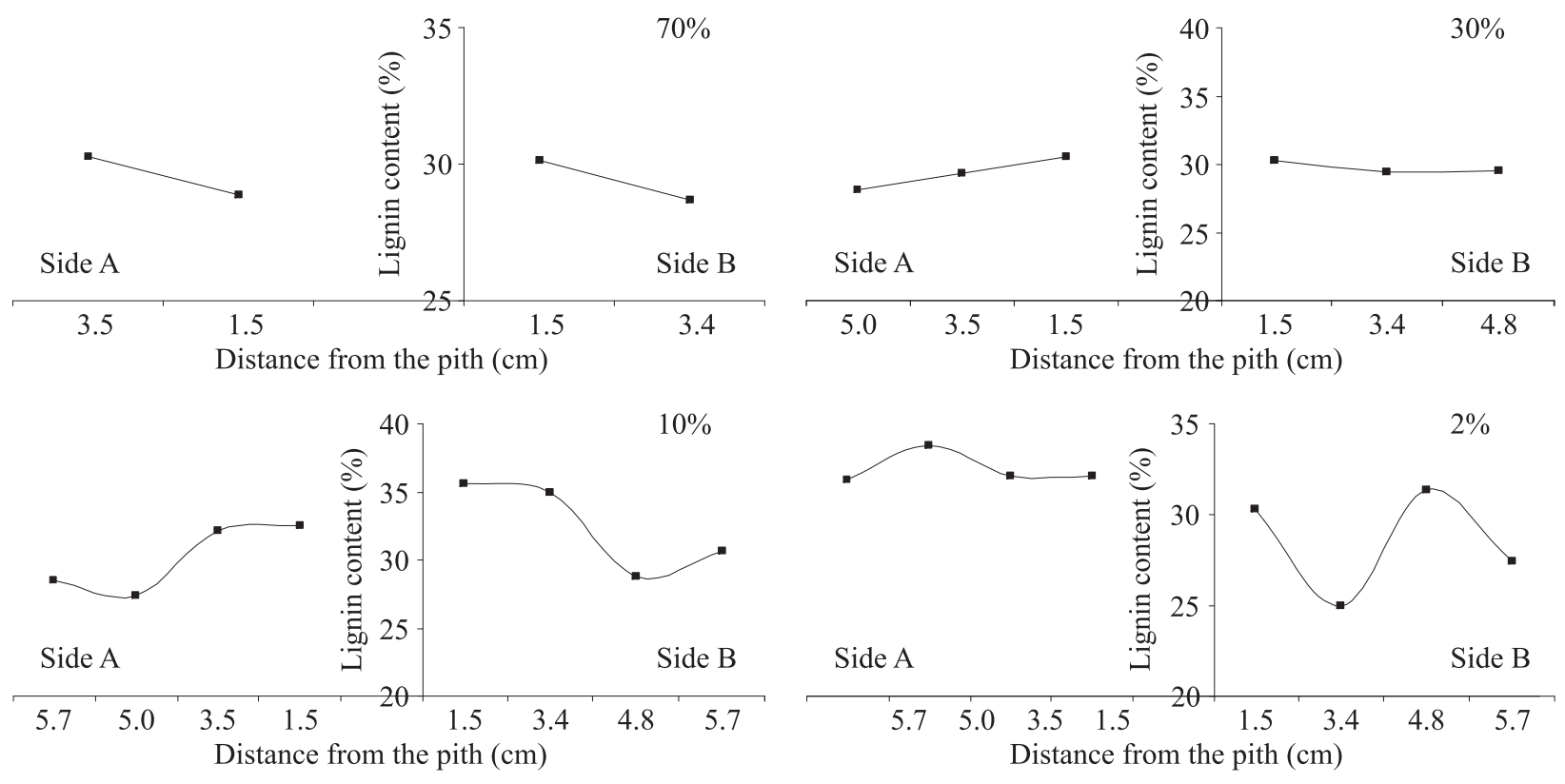

Figure 5 - Radial variation of total lignin content in wood from a clone of Eucalyptus grandis W.Hill ex Maiden x Eucalyptus urophylla S. T. Blake, for diameter class $11.4 \mathrm{~cm}$.

Figura 5 - Variação radial do teor de lignina total na madeira do clone de Eucalyptus grandis W.Hill ex Maiden x Eucalyptus urophylla S. T. Blake para a classe diamétrica $11,4 \mathrm{~cm}$.

Cerne, Lavras, v. 17, n. 3, p. 283-291, jul./set. 2011 
lignin content again failed to show a well defined pattern of radial variation. Yet it was observed that, overall, higher lignin contents are found near the pith while lower lignin contents are found near the sapwood, similarly to results found for diameter class $14.2 \mathrm{~cm}$.

Figure 6 provides radial variation of total lignin content in wood from the clone being assessed for diameter
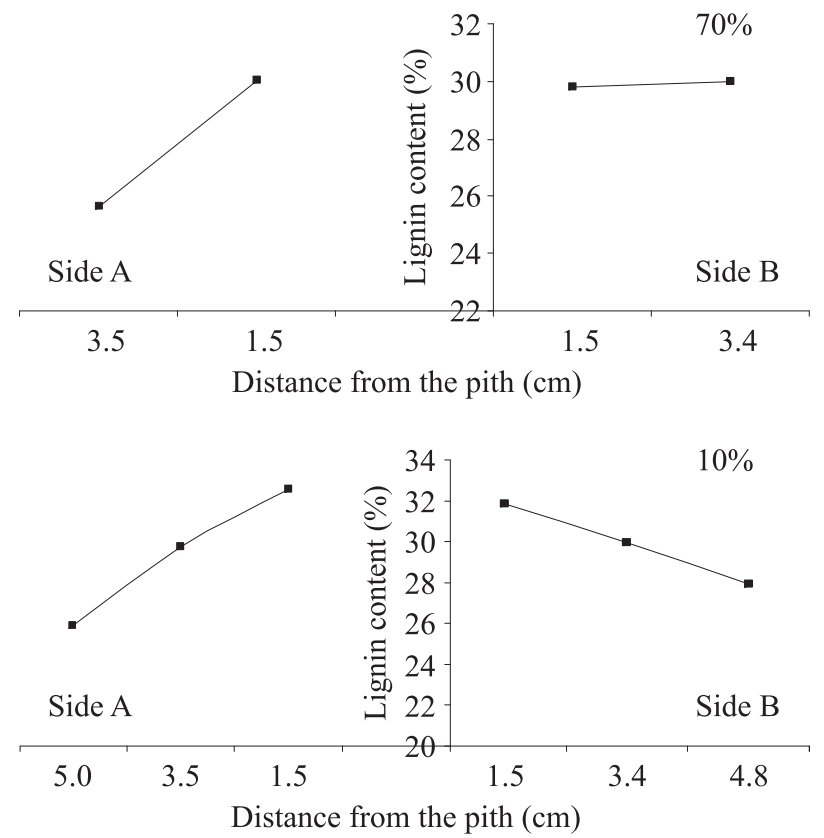

class $8.1 \mathrm{~cm}$, per relative height. Here, lignin content is noted to show a decreasing pattern of radial variation with increasing distance from the pith, particularly at the $2 \%$ and $10 \%$ portions of the commercial trunk. Also, higher lignin contents were overall found near the pith while lower lignin contents were found near the sapwood, similarly to results found for diameter classes $14.2 \mathrm{~cm}$ and $11.4 \mathrm{~cm}$.

Figure 6 - Radial variation of total lignin content in wood from a clone of Eucalyptus grandis W.Hill ex Maiden x Eucalyptus urophylla S. T. Blake, for diameter class $8.1 \mathrm{~cm}$.

Figura 6 - Variação radial do teor de lignina total na madeira do clone de Eucalyptus grandis W.Hill ex Maiden x Eucalyptus urophylla S. T. Blake para a classe diamétrica $8,1 \mathrm{~cm}$.

\section{CONCLUSIONS}

For diameter class $14.2 \mathrm{~cm}$, a reduction occurred to start with, followed by an increase in amounts of total extractives, from the base to the top of trees. Diameter classes $11.4 \mathrm{~cm}$ and $8.1 \mathrm{~cm}$ showed a similar pattern.

For diameter class $8.1 \mathrm{~cm}$, higher total lignin contents were found in positions near the tree base, particularly at the $2 \%$ height portion. The same happened with diameter classes $14.2 \mathrm{~cm}$ and $11.4 \mathrm{~cm}$.

Overall, extractives and total lignin contents in the relevant wood showed decreasing variation with increasing distance from the pith and tended to be concentrated in positions close to the tree base.

\section{REFERENCES}

ANDRADE, A. M. de. Efeitos da fertilização mineral e da calagem na produção e na qualidade da madeira e do carvão de eucalipto. 1993. 105 f. Tese (Doutorado em Ciência Florestal) - Universidade Federal de Viçosa, Viçosa, 1993.

\author{
ASSOCIAÇÃO BRASILEIRA TÉCNICA DE \\ CELULOSE E PAPEL. Normas técnicas ABTCP. São \\ Paulo, 1974.
}

BARRICHELO, L. E. G.; BRITO, J. O. Química da madeira. Piracicaba: ESALQ, 1985. 125 p.

Cerne, Lavras, v. 17, n. 3, p. 283-291, jul./set. 2011 
GOLDSCHIMID, O. Ultraviolet spectra. In: SARKANEN, K. V.; LUDWIG, C. H. Lignins: occurrence, formation, structure and reactions. New York: J. Wiley Interprice, 1971. p. 241-298.

GOMIDE, J. L.; DEMURE, B. J. Determinação do teor de lignina em material lenhoso: método Klason modificado. O Papel, São Paulo, v. 47, n. 8, p. 36-38, 1986.

HASELEIN, C. R.; LOPES, M. de C.; SANTINI, E. J.; LONGHI, S. J.; ROSSO, S.; FERNANDES, D. L. G.; MENEZES, L. F. de. Características tecnológicas da madeira de árvores matrizes de Eucalyptus grandis. Ciência Florestal, Santa Maria, v. 14, n. 2, p. 145-155, mar./abr. 2004.

KLOCK, U.; MUNIZ, G. I. B.; HERNANDEZ, J. A.; ANDRADE, A. S. Química da madeira. 3. ed. Curitiba: UFPR, 2005. 86 p.

LIMA, S. R. de; OLIVEIRA, G. S. de; MORAIS, S. A. L.; NASCIMENTO, E. A. do; CHANG, R. Estudo dos constituintes macromoleculares, extrativos voláteis e compostos fenólicos da madeira de candeia - Moquinia polymorpha (less.) dc. Ciência Florestal, Santa Maria, v. 17, n. 2, p. 145-155, abr./jun. 2007.

PÁDUA, F. A. de. Amostragem para avaliação da densidade básica da madeira de um híbrido de Eucalyptus grandis W.Hill ex Maiden x Eucalyptus urophylla S. T.
Blake. 2009. Tese (Doutorado) - Universidade federal de Lavras, Lavras, 2009.

PEREIRA, J. C. D.; STURION, J. A.; HIGA, A. R.; HIGA, R. C. V.; SHIMIZU, J. Y. Características da madeira de algumas espécies de eucalipto plantadas no Brasil. Colombo: Embrapa Florestas, 2000. 113 p. (Embrapa Florestas, Documentos, 38).

PETTERSEN, R. C. The chemical composition of wood. In: ROWELL, R. (Ed.). The chemistry of solid wood. Washington: American Chemical Society, 1984. p. 54-126.

SILVA, J. de C.; MATOS, J. L. M. de; OLIVEIRA, J. T. da S.; EVANGELISTA, W. V. Influência da idade e da posição ao longo do tronco na composição química da madeira de Eucalyptus grandis Hill ex. Maiden. Revista Árvore, Viçosa, v. 29, n. 3, p. 455-460, 2005.

SILVÉRIO, F. O.; BARBOSA, L. C. de A.; GOMIDE, J. L.; REIS, F. P.; PILÓ-VELOSO, D. Metodologia de extração e determinação do teor de extrativos em madeiras de eucalipto. Revista Árvore, Viçosa, v. 30, n. 6, p. 1009-1016, 2006.

TRUGILHO, P. F.; LIMA, J. T.; MENDES, L. M. Influência da idade nas características fisico-químicas e anatômicas da madeira de Eucalyptus saligna. Cerne, Lavras, v. 2, n. 1, p. 94-11, 1996.

Cerne, Lavras, v. 17, n. 3, p. 283-291, jul./set. 2011 